comunità toccate dalle cure religiose e culturali di Mons. Sbrocchi e dell'interazione con la maggioranza anglofona.

Queste memorie vengono ad integrare quanto di autobiografico, dopo la loro pubblicazione, è ormai facile riconoscere nel romanzo Cuore ingrato (Legas, 2002). L'opera, che vede la luce quando il suo autore ha ormai ottanta anni, ruota intorno alla storia serena di un ragazzo, Pasqualino Gentilcuore, le cui vicende di emigrazione, sempre vissute con il sostegno di Don Antonio che ne è il consigliere fidato, contano molteplici partenze e abbandoni (prima quello del paese natale, poi del Meridione e in seguito dell'Italia, per approdare infine in Canada) e in seguito a ciascuno di essi, una corona di domestici successi. Si tratta di un romanzo di valori: sacrificio, fede, famiglia, lavoro, ed ha di peculiare il fatto di proporsi anche come opera celebrativa della storia egregia e travagliata del sud d'Italia, dai suoi albori al secondo dopoguerra. L'espediente narrativo per quello che si concretizza in un lungo excursus storico, è dato da un discorso di Don Antonio ai suoi ragazzi, fondato sul presupposto che conoscere il passato permette di capire i popoli. E Mons. Sbrocchi fa con questo romanzo quello che ha fatto con le sue chiese: costruisce cioè, alla Carducci, un volto illustre, carico di storia romana e cristiana per la sua gente.

Oltre che con la memorialistica e la narrativa, Mons. Sbrocchi si è cimentato più volte con la poesia. Tra gli altri volumi - Piccapù (Legas, 1993); Un sorriso e qualche lacrima (Legas, 1996) — il più recente, Dalle regioni d'Italia (Legas, 1998), spicca per l'interesse dell'organizzazione. La raccolta, il cui metro varia tra quartine di ottonari ed endecasillabi, è divisa in sezioni. Ciascuna di esse è ispirata ad una regione italiana e mentre si apre con componimenti dedicati a quelle caratteristiche del paesaggio e del costume per cui tale regione è più celebre si sviluppa poi - con un fare che ricorda in un certo modo i canti di San Francesco e San Domenico nel Paradiso - con versi dedicati a personaggi storici di fama e a contemporanei originari del luogo e ora concittadini nel nuovo mondo. Il volume si conclude con una sezione dedicata agli emigranti e alla loro relazione con la patria lontana e, come o forse più che in altri libri della diaspora, anche in questo che ha voluto cantare da lontano la varietà dell'Italia, emerge un'immagine ideale della patria, vicina a quella in cui Manzoni aveva sperato e che aveva descritto come: "Una [...] di lingua, d'altare, di memorie, di sangue e di cor".

\title{
CRISTINA CARACCHINI
}

Queen's University

Salvatore Taormina. Il cuore oltre l'Oceano. Ottawa, Ont.: Legas, 2005. Pp. 282. ISBN 881-901-53-X \$16.

Il cuore oltre l'Oceano begins with a series of flashbacks. Luciano Moriga, the novel's protagonist, is aboard a trans-Atlantic flight to New York City. He has left Palermo to visit his beloved Vera Verasca. Luciano Moriga is educated, of a small yet decent bourgeois family, and he works as a television journalist for a local news station in Palermo. He is a typical borghese of his gender and age, in every sense 
but one: his mother is deceased. Since Luciano is self-consciously not a mammone, that particular breed of ltalian males who resides with his parents until early middle age (or beyond), he projects his desire for a strong maternal figure upon Vera, an educated younger woman. Vera is the daughter of an extensive family that is lower in social status and class than Luciano's. Vera's father, Rocco Verasca, glares furiously down from his patriarchal throne on Luciano's advances, attempting to discern in every one of Luciano's gestures or words an insult against his authority or an opportunity to sabotage their love. Eventually, Rocco's brother Joseph obtains permission from the INS to bring Rocco and his family to America; Rocco's explicit motives for emigration are financial-his true motives are those of a jealous father who cannot stand to see his daughter Vera marry Luciano (or so it would seem).

The novel sets the stage in this way for a reunion in America that will play itself out as an Oedipal melodrama, a class conflict, or both. And this remains true, even as the dramatic action and characterizations are subordinated to another matter: the novel's rendering of the linguistic world of the post-World War Two Italian immigrant. This subordination intensifies as the novel shifts location from Sicily to New York City, where the Sicilian immigrants (and Luciano) must find ways to communicate in three distinct languages: Italian, their regional Sicilian dialect, and English. There is a fourth language whose identity is a composite of the previous three; in his introduction to the novel, Taormina calls it "italiese" (a combination of "Italiano" and "Inglese"), but at other times it is referred to as "American-Sicilian" or "Sicul-American."

It is here, at the intersection of the novel's linguistic design and its melodramatic plot, that Il cuore oltre l'Oceano both succeeds and fails. As Taormina elaborates the characterizations and dramatic conflicts suggested in the opening chapters, the narration often digresses to explain any number of possible semantic traps into which a character (most often Luciano) has fallen. Take, for example, the following scene, in which the young Luciano must decipher the sympathetic Joseph Verasca's "italiese":

Ora conoscerai Sarah, mia moglie, e alcuni dei miei figli, anzi tutte le femmine. Hanno finito di faticari e sono tornate a casa. Avrai modo di riposare, fare $u$ sciauar e, vistu chi si addiiunu, potrai farti un senguiscio. Tra dui-tri urati, iiamu nzemmula a truvari Vera. Andremmo anche a un dinner-dance. Sei contento?

The paragraph is rife with what linguists refer to as "code-switching," or the habit of jumping between and combining languages in speech, as English and Italian, Italian and Sicilian, and Sicilian and English are all combined, sometimes in the words themselves. The paragraph that follows this monologue is a prolonged explanation of Luciano's attempt to make sense of it all. The narration offers several possible interpretations (in this case, it is the word "sciauar," or "shower," that confounds Luciano) until it arrives at the correct one. While the contrast is at times comical, the repeated effect is lessened, page after page, and chapter after chapter, by the author's italics, long explanations of the words, and 
exhaustive search for possible meanings. The linguistic discourse does not consist solely of semantic jokes and investigations-at times, the digressions provoke flashbacks (as when Luciano remembers his trip to Ellis Island while rummaging through his notes after returning to Palermo) and even narrative devices that are integral to the chronological movement of the plot; the latter occurs when Luciano must negotiate the meaning of the word "bille," and the digression unfolds as a chronological transition that might be compared to the cinematic editing effect known as a "wipe." In almost every such case, the narration intrudes with explanations that resemble the interventions of the ancient Greek gods who suddenly appear in Homer to rescue one person and destroy another.

Occasional passages of well-written fictional prose stand apart from these digressions. The early contrast between Luciano's father and Vera's father uses linguistic differences to great effect (and without explanation), while sparingly used metaphors and allusions amplify the sometimes mythical characterizations (as when Luciano suggests that not even the Cyclops Polyphemus could digest an entire American sandwich - see "senguiscio" above - then tells Joseph how the engagement ring he bought for Vera "cost him an eye"). But the most important and well-crafted scene in the novel is that in which Taormina describes the "dinner-dance" mentioned by Joseph. Taormina transforms the dance into a ritual enactment of long-standing political divisions in the Italian-American community. These explain the novel's many references to the debate that took place in the 1990 s over the Iralian voting rights of Italian immigrants living abroad, and it also gently uses popular music to render the profound cultural differences that separate the immigrant community's generations. These matters are dramatized at a very high level, where they take contemporary as well as historical forms (as when Rocco and his nemesis debate the Italian national anthem and the Risorgimento). The narration moves seamlessly from the generational divisions and political debates into a stunning description of a performance of Italian music by a local African-American singer. All the while, Luciano and Vera sit at the dinner table, trading furtive and longing glances. It is a scene that ranks among the best in recent fiction about Italian immigrants living in North America.

The problem remains, however, that such scenes are often not integrated with the novel's extensive linguistic discourse. While the novel's linguistic digression are diverse, comic, insightful, and often surprising, they are also repetitive and abstruse, and the novel is divided as a result. On the one hand, it is a melodramatic and modern love story; on the other it is an experiment in linguistic ethnography. The two complement one another at times, but more often than not they stand apart. This division produces what is perhaps the novel's most interesting effect: Luciano must overcome the linguistic differences that keep him from understanding Joe Verasca and the other Italian-American immigrants.

Il cuore oltre l'Oceano is distinct in one important way from other varieties of writings by or about Italian-Americans. Italian emigration, which determined much of the earlier mythology of the community's life, did not end with the closure of Ellis Island as a point of debarkation. Rather, trans-Atlantic travel following World War Two collapsed time in such a way that it weakened the immigrant's 
sense of regional detachment. While regional variations among the earlier immigrants were slowly lost to assimilation (see, for example, Fred Gardaphe's discussion of Jerre Magione's writings in Italian Signs, American Streets), they remained intact for the less extensive immigration of the post-World War Two era. In this sense, the later, post-World War Two Italian immigration to North America is characterized in most cases by a heightened regional self-awareness. Italy and its regional variations were no longer a distant and fading memory, but rather a source of increased economic, cultural, and lexical possibilities. With respect to the latter, Taormina has supplied a glossary of terms to his readers. And should readers desire to study Taormina's linguistic experiment in its original Sicilian context, they can always turn to J.K. Bonner's Introduction to Sicilian Grammar, which is published by Legas as well.

\section{Henry Veggian}

University of North Carolina at Chapel Hill

\section{Antonio D'Alfonso. A Friday in August. Translated by Jo-Anne Elder. Toronto: Exile Editions, 2005. Pp. 117. ISBN 1-5509-6639-1 \$19.95 \$15.95 US}

Pubblicato in francese con il titolo Un vendredi du mois d'aồt e tradotto in inglese da Jo-Anne Elder, l'ultimo romanzo di Antonio D’Alfonso è il secondo episodio di una serie iniziata nel 1990 con Avril ou l'anti-passion (in inglese Fabrizio's Passion) che vede come protagonista Fabrizio Notte, regista di film indipendenti alla ricerca di se stesso. Il testo, che nel 2005 ha vinto il prestigioso Trillium Award, racconta del viaggio fatto da Fabrizio nella natìa Montreal per presentare il suo ultimo lavoro, Antigone Pacifica, accolto in maniera controversa da critica e pubblico. A destare l'interesse del lettore non è tuttavia ciò che succede a Fabrizio durante questo caldo venerdì di fine agosto, e cioè la pura vicenda narrativa, ma, al contario, le memorie e i ricordi, evocati dal ritorno nei luoghi dell'infanzia. Quello che conta in pratica, non è tanto il viaggio esteriore e fattuale quanto quello interiore, più complesso, sofferto e intenso.

La conseguenza a livello strutturale è quella di un testo che procede in modo non lineare, costantemente sospeso tra la narrazione dei fatti (il viaggio di Fabrizio, i suoi incontri, la vicenda del cognato) e le varie inserzioni che interrompono la narrazione primaria. Ad esempio, nella sezione 18, l'incontro con l'amico d'infanzia Thomas dà luogo ad un flashback in cui Fabrizio rievoca il tradimento dell'amico e della moglie Ada ed il conseguente sordo dolore. Contribuiscono a creare questa sorta di duplice testualità anche alcune inserzioni oniriche (si veda per esempio la sezione 2), alcune citazioni mitologiche (107-108) e, soprattutto, la profonda predisposizione lirica del narratore. Come scrive del resto lo stesso Fabrizio commentando il libro che intende leggere durante il volo che lo porterà da Toronto a Montreal (Sperm Warms di Robin Baker): "I prefer autobiographies to novels. I don't like fiction. I don't like people telling me stories. I want to hear the texture of the writer's voice, and there are so few true voices to be heard in books published in North America" (37). E ancora: "Too many people produce 